\title{
Grounding System Impedance: Range of Frequency Linearity
}

\author{
VOJIN I. KOSTIĆ, University of Belgrade, \\ Electrical Engineering Institute „Nikola Tesla“, Belgrade \\ Professional paper \\ UDC: 621.316 .99
}

DOI: 10.5937/tehnika2106791K

\begin{abstract}
The measurement of grounding system impedance of in-service power facilities is a very complex issue since the power system frequency interference and harmonic frequencies may adversely affect the measurement. Recently, to overcome this problem the Frequency Shift Method (FSM) has been proposed. FSM requires that two of three test frequencies must be above power system frequency (in our case $50 \mathrm{~Hz}$ ). However, due to the nonlinear dependence of the grounding system impedance versus frequency, the choice of test frequencies is not arbitrary. In this paper, this issue is experimentally examined based on the analysis of grounding system impedance linearity range. For this purpose, the grounding system impedance, for a sample of 16 substations ( $H V$ and $M V)$, is examined. We find that the highest test frequency should be $\leq 80 \mathrm{~Hz}$.
\end{abstract}

Key Words: Grounding, Grounding system impedance, Frequency Shift Method

\section{INTRODUCTION}

The grounding system has an important role to maintain safe and reliable operation of power facility (usually substation). In order to evaluate the safety and reliability of the grounding system, grounding system impedance should be periodically tested. The goal is to perform the test when the substation is in-service (to avoid interruption of service and costly downtime). The measurement in the in-service substations (MV and especially $\mathrm{HV}$ ) is an extremely challenging task (due to the presence of high conductive interference in the grounding system, and very low impedance of the grounding system $(\leq 0.5 \Omega)$ ). Consequently, there is a continual interest in the research papers [1] $-[5]$ and technical standards [6] - [8] to improve the measurement procedures of the grounding system.

For the purposes of the grounding system performance analysis, many mathematical tools have been developed, among the others [9]. Unlike the theoretical approaches, empirical approaches are not widely available in the literature due to the arduous work involved, the difficulty to obtain permissions, and safety restrictions. Briefly, in order to avoid the impact of po-

Author's address: Vojin Kostić, University of Belgrade, Electrical Engineering Institute „Nikola Tesla“, Koste Glavinića 8a, Beograd

e-mail: vojin@ieent.org

Paper received: 09.11.2021.

Paper accepted: 22.11.2021. wer frequency $(50 \mathrm{~Hz})$ on the grounding system impedance measurement, the Frequency Shift Method (FSM) have been proposed [10] - [14]. FSM successively uses test current at three frequencies $\left(f_{i} \neq 50 \mathrm{~Hz}\right.$, $i=1,2$ and 3). By using linear regression on the measured results for grounding system impedance at $f_{1}, f_{2}$ and $f_{3}$, the grounding system impedance, $Z$ at $50 \mathrm{~Hz}$, can be estimated. The method basically assumes that the impedances measured at $f_{i}(i=1,2,3)$ are collinear points (within the limits of the measurement uncertainty) in a $f$ - $Z$ plot.

In this paper, we will elaborate on the choice of maximum allowable value for the test frequency $f_{3}$. Namely, the choice of the highest test frequency $\left(f_{3}\right)$ is mostly limited by the effects of grounding system impedance nonlinearity. Due to nonlinearity, the measurement result for $f_{3}$ may not be collinear with the results for $f_{l}$ and/or $f_{2}$.

Such a deviation may introduce a significant systematic error in respect to assessing the impedance at $50 \mathrm{~Hz}$. Hence, we are interested for range of the linear part of ground impedance (versus frequency) in the circumstances when the grounding grid is heavy reactively loaded by connected cables and/or overhead ground wires.

Based on a statistically representative sample of totally 16 power facilities (voltage range: $35 \mathrm{kV}, 110$ $\mathrm{kV}, 220 \mathrm{kV}$ and $400 \mathrm{kV}$ ), we will empirically elaborate linear range of the ground impedance in term of frequency. 
The paper is divided into six sections. The first section gives a brief overview of the problem. The basic aspects of linear regression in the context of the grounding system impedance measurement are outlined in the second section. In the third section the concept of the experiment was elaborated. Two typical, but very different, grounding system impedance behavior in the frequency range $f=40 \mathrm{~Hz}$ to $120 \mathrm{~Hz}$ were analyzed in the fourth section. The next section examines the range of linearity. Finally, some conclusions are drawn in the sixth section.

\section{THE PRINCIPLE OF LINEAR REGRESSION}

In this section we will consider basic aspects of linear regression in the context of the grounding system impedance measurement.

The measurements are performed successively at three test frequencies (e.g., $f_{1}=40 \mathrm{~Hz}, f_{2}=60 \mathrm{~Hz}$ and $f_{3}=75 \mathrm{~Hz}$ ). The measurement results are presented graphically where the impedance is a function of frequency. In an ideal case, the measurement results lie on a straight line in the diagram of impedance against frequency. In that case, the value of grounding system impedance, at $50 \mathrm{~Hz}$, lies on the straight line, too. However, practical measurement results are not collinear, mostly, due to the frequency nonlinearity of the grounding system impedance. So, we need to determine a similar, but practically useful, straight line that will deviate from any of the measured points with minimum error (in the mean square sense). The regression line minimizes the aforementioned error.

Formally, the analytical problem comes down to determining the coefficients $a$ and $b$ for the straight line

$$
y=b x+a
$$

Here (1) represents the regression line, where $x$ refers to the frequency, and $y$ refers to the impedance. In this context, considered measurements results are: $\left(x_{1}, y_{1}\right),\left(x_{2}, y_{2}\right)$ and $\left(x_{3}, y_{3}\right)$. Therefore, according to [15] we have:

$$
b=\frac{\sum_{i=1}^{n} x_{i} y_{i}-\frac{1}{n}\left(\sum_{i=1}^{n} x_{i}\right)\left(\sum_{i=1}^{n} y_{i}\right)}{\sum_{i=1}^{n} x_{i}^{2}-\frac{1}{n}\left(\sum_{i=1}^{n} x_{i}\right)^{2}}
$$

and

$$
a=\frac{\sum_{i=1}^{n} y_{i}-b \sum_{i=1}^{n} x_{i}}{n}
$$

Thus, putting $\mathrm{x} \cong 50[\mathrm{~Hz}]$ in the equation (1), we obtain assessed value for $Z[\Omega]$.

\section{THE CONCEPT OF EXPIRIMENT}

The measurement setup is shown in Figure 1.

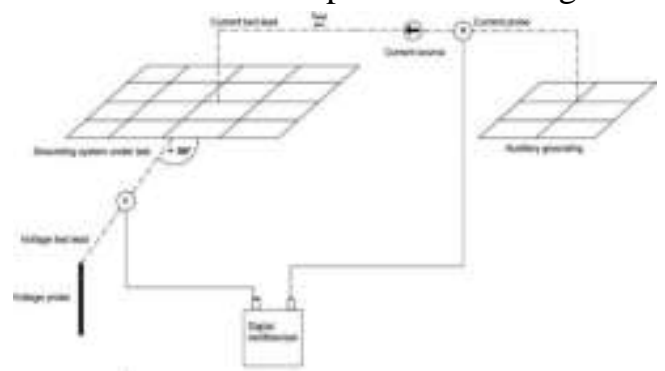

Figure 1-Measurement setup

In our experiment, we will use so called the nonconventional Fall-of-Potential measurement method [16] - [17]. More precisely, the angle between the measurement trace (voltage test lead) and the current's injection path should be $90^{\circ}$. In practice, due to physical obstacles, this requirement is difficult to meet. Namely, substations are usually built up in urban or suburban zones. Therefore, it's quite difficult to find a more than one direction free from physical obstacles where one can spread the test conductors. Similarly, in rural areas the substation can be surrounded by terrain's obstacles and/or vegetation. So, in reality the value for $\theta$ is between $60^{\circ}$ and $90^{\circ}$. This fact has been elaborated recently in [18].

Considering the fact that reduction factor, $r$, is a complex number and can alter the measurement results of grounding system impedance, a current test lead in each of the tested substations, was formed by using an overhead line without overhead ground wire or with overhead ground wire made of steel (cross section $35 \ldots 50 \mathrm{~mm}^{2}$ ). Also, in MV substations, which are working in predominantly cable networks, we used a cable with synthetic (or dry) insulation, which sheaths were disconnected during the measurement campaign in substations which grounding system was under the test. In order to avoid the influence of induced voltages and currents occurring in the power line which is used as a current test lead, we chose a power line with only one circuit. This applies particularly to $110 \mathrm{kV}$ overhead lines where some circuits are often erected on the same tower (paralleling circuits of $110 \mathrm{kV}$ overhead lines on the same towers is common).

The ground potential rise (GPR) was measured by a rod which was driven into the ground at the reference point and a voltage test lead which connects this rod to the oscilloscope. The reference point (reference ground) is considered to be sufficiently far, when the variation in GPR with increasing distance becomes small enough.

A key part of the measurement setup is the variable frequency current source (California Instruments, type: $5001 \mathrm{iM} / 10001 \mathrm{iM} / 15001 \mathrm{iM}$ ), which is based on the 
combining of the variable frequency, voltage and current functions. The monitoring of the GPR and test current signals was done by two-channel oscilloscope (Metrix, type Scopix III OX7042 and Metrix, type HX0073, respectively). The recording of these signals was performed by the acquisition software loaded on a laptop computer. Discrete Fourier Transform (DFT) is used for the processing of the signals, which are further digitally filtered. The values of measured grounding system impedance are obtained as the ratio of the DFT of the resulting GPR signal and the DFT of the injected current signal. This is done for all of the test frequencies. After that, the obtained results should be presented graphically.

\section{FREQUENCY BEHAVIOR OF THE GROUNDING SYSTEM IMPEDANCE}

In order to clarify the nonlinearity of the grounding system impedance we refer to Figure 2 .

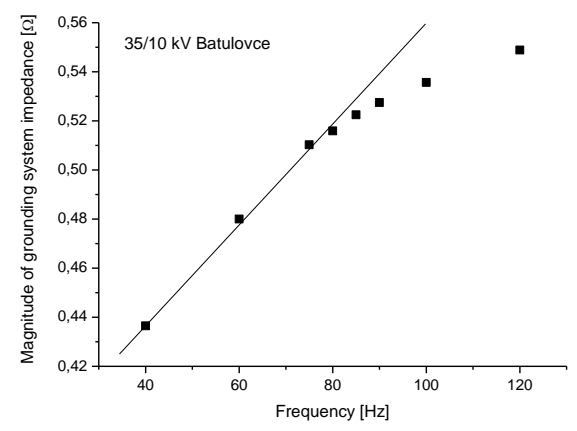

(a)

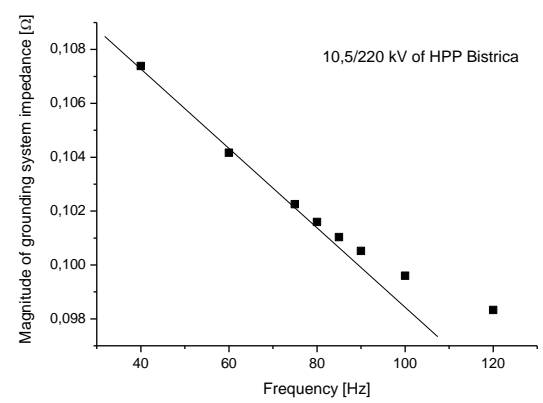

(b)

Figure 2 - Two typical behavior of grounding system impedance in a frequency range $40-120 \mathrm{~Hz}$; reference straight line, - measurement points (a) 35/10 kV Batulovce, (b) 10,5/220 kV of HPP Bistrica

Namely, Figure 2 shows two typical, but very different, grounding system impedance behavior in the frequency range $\mathrm{f}=40$ to $120 \mathrm{~Hz}$, when the substation is in-service.

In both cases the ground impedance behaves nonlinearly. It is important to note that increasing or decreasing impedance vs. frequency depends of the grounded part of the transmission infrastructure (overhead ground wires and/or sheaths of the cable lines, as well as other underground metallic structures that are in the immediate vicinity of the tested grounding system), but depends as well as of the electrical properties of soil.

One can observe from Fig. 2 that the linear range of the grounding system impedance is up to $80 \mathrm{~Hz}$. In order to corroborate this fact, in the next section we will examine impedance behavior for a statistically significant sample of substations.

\section{VALIDATION OF THE RANGE OF LINEARITY}

The experiments have been carried out in 16 power facilities (voltage range: $35 \mathrm{kV}, 110 \mathrm{kV}, 220 \mathrm{kV}$ and $400 \mathrm{kV}$ ) in Serbia. A graphical representation of the measurement results is given in Figs. 3 to 6. Frequency dependence of grounding system impedance in MV substations (rated voltage $35 / 10 \mathrm{kV}$ ) has been shown in Fig. 3.

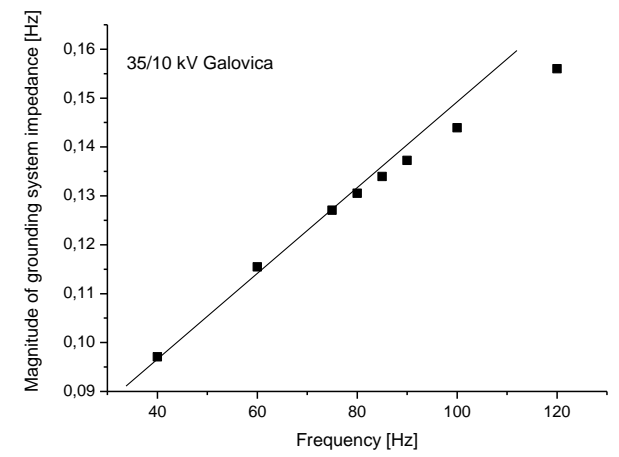

(a)

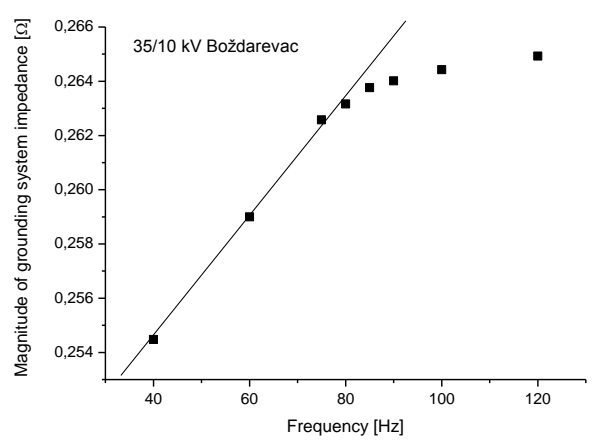

(b)

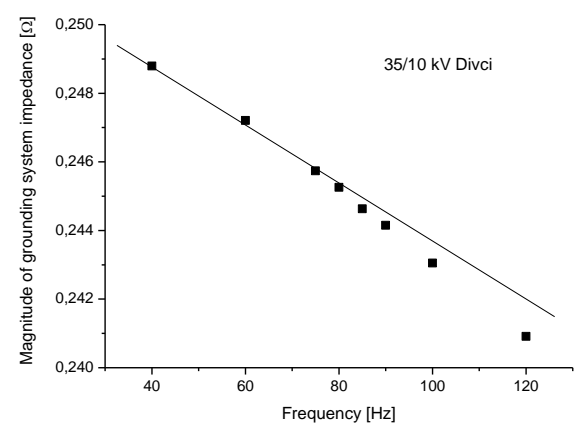

(c) 


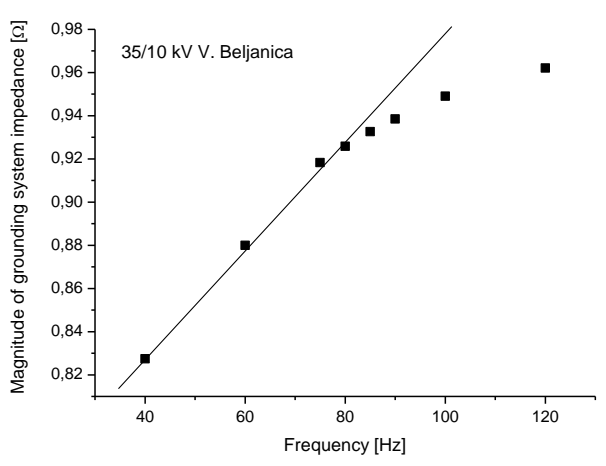

(d)

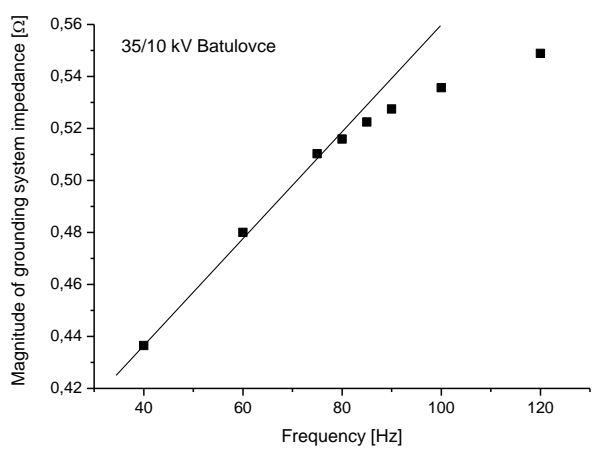

(e)

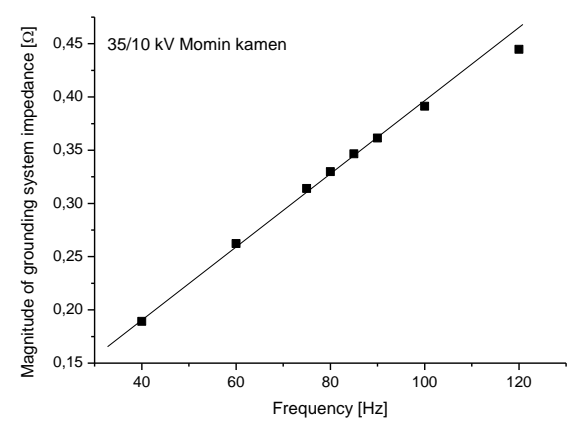

(f)

Figure 3 - Linear range of grounding system impedance vs frequency in MV substations

These are typical distribution substation, designed to operate in $10 \mathrm{kV}$ network with isolated (ungrounded) or low-impedance grounded neutral. The frequency dependence of grounding system impedance in HV substations (rated voltage: $110 \mathrm{kV}, 220 \mathrm{kV}$ and $400 \mathrm{kV}$ ) have been shown in Figs. 4 to 6, respectively. In this kind of facilities, all neutrals on the high voltage side are effectively (solidly) grounded. Consequently, because three-phase loads are unbalanced and the geometry locations of three-phase lines are not completely symmetrical, there is a stray current (dominantly at $50 \mathrm{~Hz}$ ) which flow through the ground grids of those facilities. Generally, this current is several amperes, but for some substations it may be about dozens of amps [20]. Furthermore, the stray current is time-varying - it changes as the network load changes. This is an additional problem.

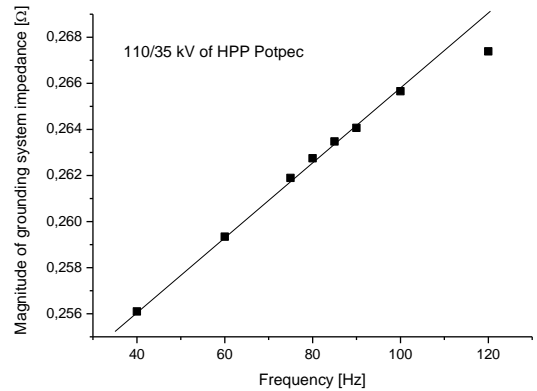

(a)

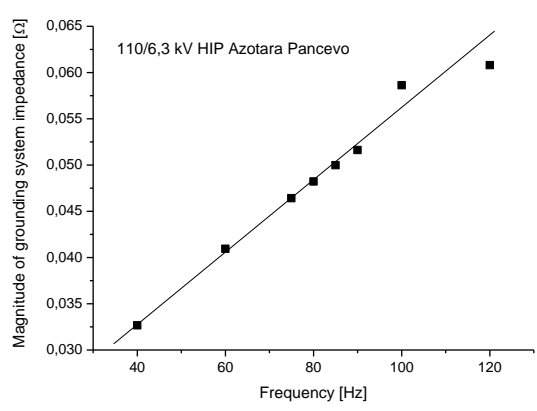

(b)

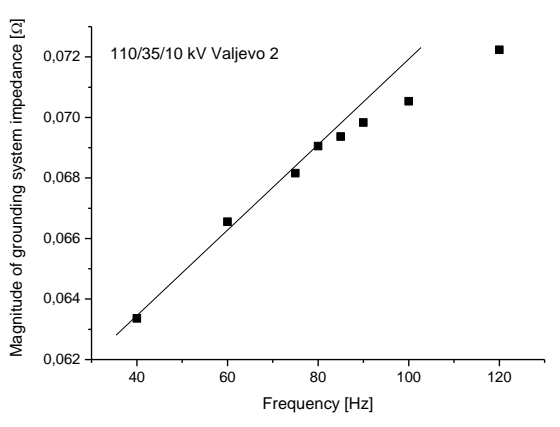

(c)

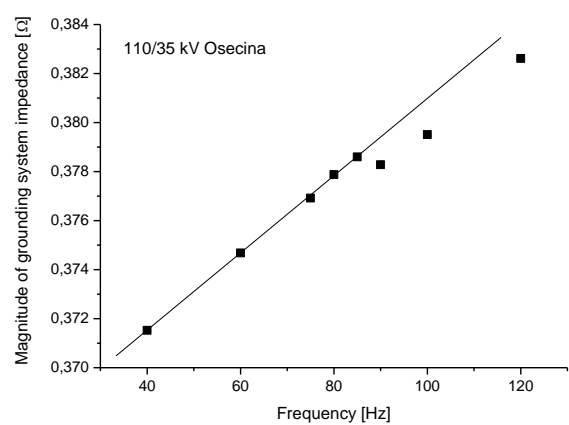

(d)

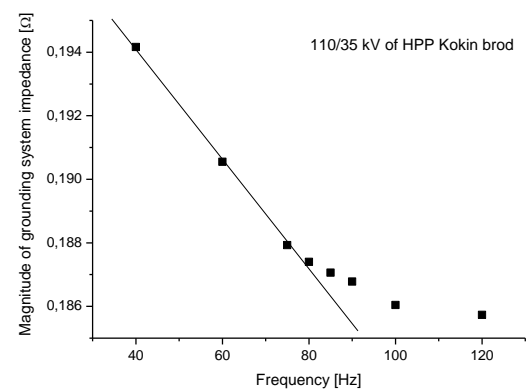

(e) 


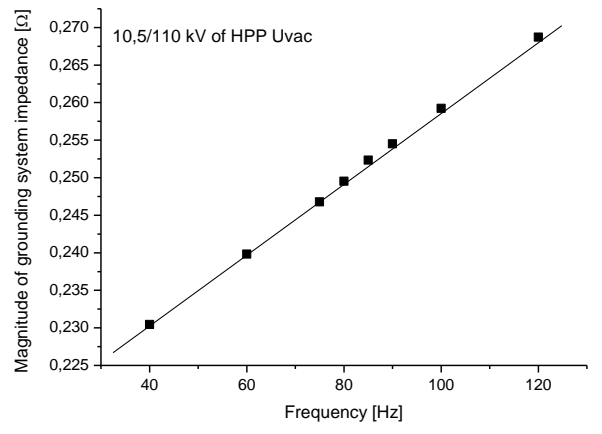

(f)

Figure 4 - Linear range of grounding system impedance $v$ s frequency in $H V$ substations rated voltage 110/X kV

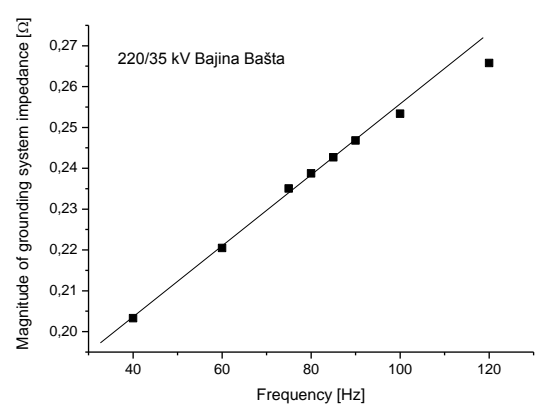

(a)

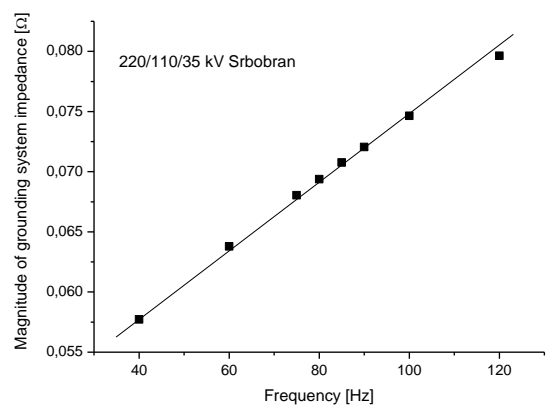

(b)

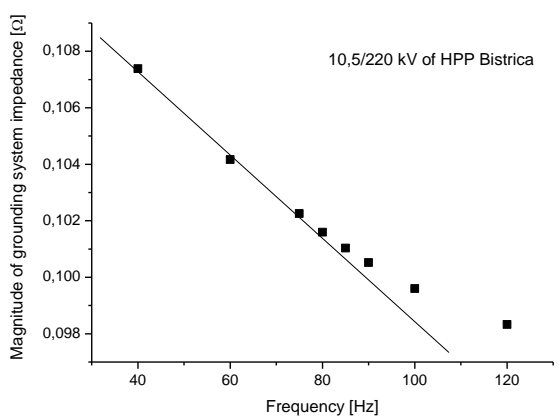

(c)

Figure 5 - Linear range of grounding system impedance vs frequency in $H V$ substations rated voltage $220 / \mathrm{K} \mathrm{kV}$

By close examination of the results shown in Figs. 3-6 it is obvious that the grounding system impedance, in all considered cases, has a linear dependence of frequency in the range up to $80 \mathrm{~Hz}$. More precisely, the upper value of the test frequency that satisfies the condition of linearity in all of the considered cases was determined to be $80 \mathrm{~Hz}$. According to that, test frequency $f_{3}$ must be $\leq 80 \mathrm{~Hz}$.

Obviously, at lower frequencies linearity is not a problem. However, at very low frequencies there is a potential danger of geomagnetically induced currents [21]. Regard to this, the safe choice of the lowest test frequency can be around $40 \mathrm{~Hz}$. Thus, in terms of relatively simple filtering of the test signal, as well as in terms of the minimum condition for the application of linear regression, we have a comfortable option to select test frequencies below $50 \mathrm{~Hz}(\mathrm{eg}$, at $40 \mathrm{~Hz}$ ) and above $50 \mathrm{~Hz}$ (eg, at $75 \mathrm{~Hz}$ ). To minimize the effects of measurement error (manual and instrumental errors), we will add another test frequency. Again, guided by the requirement that filtering is relatively simple, both in relation to the system interference signal and in relation to the already selected test frequencies, we will position the additional test frequency between $50 \mathrm{~Hz}$, on the one hand, and the highest selected test frequency $75 \mathrm{~Hz}$, on the other sides. Thus, a suitable choice may be a frequency of $60 \mathrm{~Hz}$.

Note that the above test frequencies have been elaborated as one example of choice. In other words, the choice may be different. Namely, within the constraints that depend on the behavior of the grounding system impedance, the choice of test frequencies also depends on the appropriate software solution for digital filtering. In this context, it should be noted that the relevant parameters for designing a filter at a particular test frequency are: (a) the frequency distance from the system frequency, (b) the frequency distance from the nearest harmonic (or subharmonic) of the system frequency, and (c) the level of the noise floor at the test frequency position.

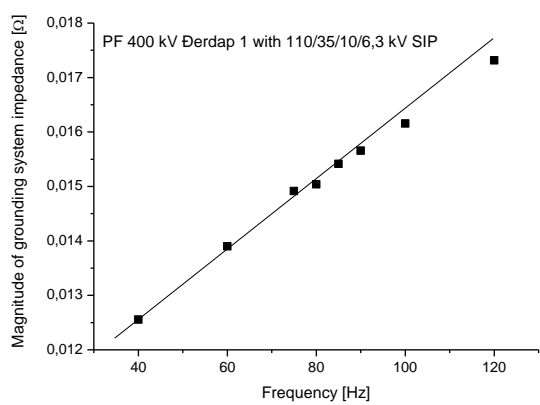

(c)

Figure 6 - Linear range of grounding system impedance vs frequency in $H V$ power facility rated voltage $400 \mathrm{kV}$

\section{CONCLUSION}

The main findings in the paper are as follows: 
- The grounding system impedance was analyzed in 16 plants (voltage ranges: $35 \mathrm{kV}, 110 \mathrm{kV}, 220 \mathrm{kV}$ and $400 \mathrm{kV}$ ).

- By the measurement on the representative sample of the energized (in-service) $\mathrm{HV}$ and MV substations, in the frequency range $40 \mathrm{~Hz}$ to $120 \mathrm{~Hz}$, it is verified that there are two quite different behaviors of the grounding system impedance (please, see Fig. 2).

- It has been found that in all considered cases the grounding system impedance is linearly frequency-dependent in the range up to $80 \mathrm{~Hz}$. Therefore the highest test frequency should be less than $80 \mathrm{~Hz}$.

Close examination of different behavior of the grounding system impedance vs frequency, will be in the focus of our further investigations.

\section{ACKNOWLEDGEMENT}

The author would like to thank to the PE Electric Power Industry of Serbia and JSC Elektromreža Srbije for support of the research work related to this paper.

\section{REFERENCES}

[1] W. C. Boaventura, I. J. S. Lopes, P. S. A. Rocha, R. M. Coutinho, F. Castro Jr, and F. C. Dart, Testing and Evaluating Grounding Systems of High Voltage Energized Substations: Alternative Approaches, IEEE Transactions on Power Delivery, Vol. 14, No.3, pp. 923-927, Jul. 1999.

[2] R. Zeng, J. He, and Z. Guan, Novel measurement system for grounding impedance of substation, IEEE Transactions on Power Delivery, Vol. 21, No. 2, pp. 719-725, Apr. 2006.

[3] H. Griffiths, P. Jones, N. Harid and A. Haddad, Proposal for measurement of earth impedance using variable frequency injection, Measurement Science and Technology, 21, 085102 (8pp), 2010.

[4] M. J. Lindinger, H. Renner, and E. Schmautzer: New optimized analysis method for measuring extended grounding systems, The 8th International Conference 2012 Electric Power Quality and Supply Reliability, 11 - 13 Jun. 2012.

[5] A. B. Lima, C. E. F. Caetano, J. O. S. Paulino, W. C. Boaventura, I. J. S. Lopes and C. F. Barbosa: An original setup to measure grounding resistances using fast impulse currents nad very short leads, Electric Power Systems Research Journal, vol. 173, pp. 6-12, Aug. 2019.

[6] IEEE Guide for Measuring Earth Resistivity, Ground Impedance, and Earth Surface Potentials of a Ground System, IEEE Standard 81-2012, Dec. 2012.
[7] IEEE Guide for Safety in AC Substation Grounding, IEEE Standard 80-2013, Dec. 2013.

[8] EN 50522, Earthing of power installations exceeding $1 \mathrm{kV}$ a.c., CENELEC European Committee for Electrotechnical Standardization, Nov. 2010.

[9] I. Colominas, J. Gomez-Calvino, F. Navarrina, and M. Casteleiro: Computer analysis of earthing systems in horizontally or vertically layer soils, Electric Power Systems Research Journal, Vol. 59, No. 3, pp. 149-156, Oct. 2001.

[10]V. Kostić, N. Raičević, and A. Pavlović, Enhanced grounding system impedance measurements for high-voltage substations, International Transactions on Electrical Energy Systems, Vol. 25, No. 9, pp. 1875-1883, Sep. 2015.

[11]V. Kostić, and N. Raičević, Grounding system impedance measurement using shifted frequency method, IEEE 5th International Conference on Power Engineering, Energy and Electrical Drives - POWERENG 2015, Riga, Latvia, LF-000124 (CD), pp. 1-4, 11-13 May 2015.

[12]V. Kostić, N. Raičević, J. Mrvić, S. Rebrić: Grounding system impedance measurement - Case study, 12th International Conference on Applied Electromagnetics - ПЕC 2015, Faculty of Electronic Engineering of Niš, Niš, Serbia, O5-6 (CD), pp. 1-4 31 Aug.-2 Sep. 2015.

[13]V. I. Kostić, N. B. Raičević, D. S. Kovačević, The choice of suitable frequencies for measurements based on FSM, Facta Universitatis, Series: Automatic Control and Robotics, Vol. 15, No. 1, pp. 9-16, 2016.

[14]V. Kostić, and N. Raičević: An alternative approach for touch and step voltages measurement in highvoltage substations, Electric Power Systems Research Journal, Vol. 130, pp. 59-66, Jan. 2016.

[15]W. J. DeCoursey: Statistics and probability for engineering applications with microsoft excel, Newnes, 2003.

[16]H. G. Sarmiento, J. Fortin, and D. Mukhedkar: Substation ground impedance: Comparative field measurements with high and low current injection methods, IEEE Transactions on Power Apparatus and Systems, Vol. PAS-103, No. 7, pp. 1677-1683, Jul. 1984.

[17]R. Southey, W. Ruan, F. Dawalibi, and M. Kizuik: Measurement and interpretation of ground impedance of substations by non-conventional fall-of-potential methods, In: Proceedings of the 2009 International Conference on Electrical Engineering (ICEE'09), Shenyang, China, 5-9 Jul. 2009.

[18]V. Kostić, N. Raičević and M. Dočić, FOP - FSM measurement - Relative position of the test con- 
ductors, 2020 21st International Symposium on Electrical Apparatus \& Technologies (SIELA), Bourgas, Bulgaria, pp. 1-4, 3-6 Jun 2020.

[19]J. He, R. Zeng, and B. Zhang, Methodology and technology for power system grounding, John Wiley
\& Sons, Singapore Pte. Ltd., 2013, Ch. 11.

[20]V. Kostić, Overview of the problems related to the impact of geomagnetic induced current (in Serbian), Tehnika, Vol. 72, No. 2, pp. 243-247, Apr. 2017.

\section{REZIME}

\section{IMPEDANSA SISTEMA UZEMLJENJA: OPSEG FREKVENCIJSKE LINEARNOSTI}

Merenje impedanse sistema uzemljenja elektroenergetskog objekta u normalnom radnom režimu, predstavlja složen istraživački zadatak. Naime, u tom slučaju neminovno je prisustvo sistemskih smetnji (na mrě̌noj frekvenciji $i$ na harmonicima), koje mogu bitno uticati na tačnost merenja. $U$ cilju prevazilaženja navedenog problema, predložen je i dokazan efikasan metod za eliminisanje sistemskih smetnji. Taj metod se imenuje kao Frequency Shift Method (FSM). FSM inherentno zahteva da dve, od tri ispitne frekvencije, budu iznad mrežne frekvencije (u našem slučaju $50 \mathrm{~Hz}$ ). Međutim, zbog nelinearne zavisnosti impedanse sistema uzemljenja u funkciji od frekvencije, izbor ispitnih frekvencija ne može biti proizvoljan. U ovom radu, eksperimentalno je verifikovan opseg linearnosti impedanse sistema uzemljenja u funkciji od frekvencije. U tom cilju, ispitivanja su obavljena na statistički reprezentativnom uzorku od 16 transformatorskih stanica srednjeg $i$ visokog napona. Ispitivanjima je ustanovljeno da bi gornja ispitna frekvencija trebala biti $\leq 80 \mathrm{~Hz}$.

Ključne reči: uzemljenje, impedansa sistema uzemljenja, Frequency Shift Method 